\title{
ANALISIS PENGARUH PELAKSANAAN PENILAIAN PORTOFOLIO TERHADAP PRESTASI BELAJAR KEWARGANEGARAAN PEMBAHASAN HAKIKAT BANGSA DAN NEGARA SISWA KELAS IX - A SMP NEGERI 2 BANGKALAN
}

\author{
Wiwik Noerwiyati \\ Guru SMP Negeri 2 Bangkalan
}

\begin{abstract}
Abstrak
Pembelajaran Kewarganegaraan yang diselenggarakan di SMP Negeri 2 Bangkalan, Kabupaten Bangkalan telah berlangsung sesuai dengan tuntutan kurikulum. Namun dalam pelaksanaan dirasa masih belum memenuhi harapan yang diinginkan. Hal ini didasarkan pada pengamatan tentang pelaksaan pembelajaran, di mana guru masih menerapkan metode konvensional yaitu metode ceramah yang kadang-kadang diselingi tanya jawab. Model pembelajaran berbasis portofolio merupakan bentuk perubahan pola piker tersebut, yaitu suatu inovasi pembelajaran yang dirancang untuk membantu peserta didik memahami teori secara mendalam melalui pengalaman belajar praktik-empirik. Berdasarkan tujuan yang telah ditetapkan, yaitu untuk memperoleh gambaran tentang pengaruh pelaksanaan penelitian portofolio terhadap prestasi belajar pada bidang studi Kewarganeegaraan dalam pembahasan Hakikat Bangsa dan Nagara, maka metode penelitian yang sesuai dengan penelitian ini adalah metode statistik korelasional. Simpulan yang dapat ditarik yaitu bahwa pelaksanaan penilaian portofolio akan mempengaruhi prestasi pembelajaran pada bidang studi Kewarganegaraan dalam pembahasan Hakikat Bangsa dan Negara siswa kelas IX-A SMP Negeri 2 Bangkalan tahun pembelajaran 2013/2014:
\end{abstract}

Kata Kunci: Prestasi Belajar PKn, Portofolio 


\section{A. Latar Belakang Masalah}

Untuk meningkatkan mutu pendidikan diperlukan perubahan pola pikir yang digunakan sebagai landasan pelaksanan kurikulum. Proses belajar mengajar yang terfokus pada guru, dan kurang terfokus pada siswa mengakibatkan kegiatan belajar mengajar lebih menekankan pada pengajaran dari pada pembelajaran. Pembelajaran sebagai perubahan dalam kemampuan, sikap, atau perilaku siswa yang relatif permanen sebagai akibat dari pengalaman atau pelatihan. Perubahan kemampuan yang hanya berlangsung sekejab dan kemudian kembali keperilaku semula menunjukkan belum terjadi peristiwa pembelajaran, walupun mungkin terjadi pengajaran. Tugas seorang guru diberbagai lembaga pendidikan formal mulai dari tingkat sekolah dasar sampai dengan perguruan tinggi adalah membuat agar proses pembelelajaran pada siswa berlangsung efektif.

Selaian fokus pada siswa pola pikir pembelajaran perlu diubah dari sekedar memahami konsep dan prinsip keilmuan, siswa juga harus memiliki kemampuan untuk berbuat sesuatu dengan menggunakan konsep dan prinsip keilmuan yang telah dikuasainya. Seperti dinyatakan dalam pilar-pilar pembelajaran UNESCO, selain terjadi learning to know (perubahan untuk tahu), juga harus terjadi learning to do (pembelajaran untuk berbuat), dan bahakan dituntut sampai pada learning to be (pembelajaran untuk membangun jati diri yang kokoh), serta learning to live together (pembelajaran untuk hidup bersama secara harmonis).

Model pembelajaran berbasis portofolio merupakan bentuk perubahan pola pikir tersebut, yaitu suatu inovasi pembelajaran yang dirancang untuk membantu peserta didik memahami teori secara mendalam melalui pengalaman belajar praktik-empirik. Model pembelajaran ini dapat menjadi program pendidikan yang mendorong kompetensi, tanggung jawab, dan partisipasi peserta didik, belajar menilai dan mempengaruhi kebijakan umum (public policy), memberanikan diri untuk berperan serta dalam kegiatan antar siswa, antar sekolah, dan antar anggota masyarakat. Selain perlu adanya perubahan pola pikir dalam hal pembelajaran, pola pikir penilaian pun perlu diubah. Penilaian itu pada hakikatnya tidak hanya dilakukan sesaat, akan tetapi harus dilakukan secara berkala dan berkesinambungan. Di samping itu, bukan hanya menafsirkan sesuatu secara parsial, melainkan harus secara menyeluruh yang meliputi proses dan hasil pertumbuhan dan perkembangan wawasan pengetahuan, sikap, serta keterampilan yang dicapai warga belajar.

Pembelajaran Kewarganegaraan yang diselenggarakan di SMP Negeri 2 Bangkalan, Kabupaten Bangkalan telah berlangsung sesuai dengan tuntutan kurikulum. Namun demikian dalam pelaksanaan dirasa masih belum memenuhi harapan yang diinginkan. Hal ini didasarkan pada pengamatan tentang pelaksanaan pembelajaran bidang studi tersebut. Dimana guru bidang studi Kewarganegaraan masih menerapkan metode konvensional yaitu metode ceramah yang kadang-kadang diselingi tanya jawab. Dalam hal penilaian (evaluasi) masih diterapkan evaluasi dalam bentuk obyektif dengan pilihan ganda, sedangkan untuk penilaian seperti portofolio, studi kasus, tes lisan yang justru saat ini dikembangkan dan sekaligus menjadi tuntutan Kurikulum dalam mengukur hasil pembelajran siswa kalau boleh disebut tidak sama sekali dilakukan oleh guru.

Kendatipun telah sering diadakan seminar-seminar ataupun lokakarya terhadap guru-guru guna meningkatkan hasil pembelajaran pada mata pelajaran, namun dan hasil penelitian masih menggambarkan belum tercapainya tujuan pembelajaran yang banyak bersifat hafalan selama ini. Dengan kata lain seolah-olah lokakarya ataupun seminar-seminar itu hanyalah formalitas belaka.

\section{B. Perumusan Masalah}

Bertolak dan latar belakang masalah di atas, maka permasalahan yang akan diteliti dapat dirumuskan sebagai berikut : 1) Bagaimanakah pelaksanaan penilaian portofolio pada bidang studi Kewarganegaraan dalam pembahasan Hakikat Bangsa dan Negara siswa kelas IX - A SMP Negeri 2 Bangkalan, Kabupaten Bangkalan tahun pembelajaran 2013/2014 Semester 1? 2) Bagaimanakah prestasi pembelajaran pada bidang studi dalam pembahasan Hakikat Bangsa dan Negara siswa 
kelas IX - A SMP Negeri 2 Bangkalan, Kabupaten Bangkalan tahun pembelajaran 2013/2014 Semester 1? 3) Adakah pengaruh pelaksanaan penilaian portofolio terhadap prestasi belajar pada bidang studi Kewarganegaraan dalam pembahasan Hakikat Bangsa dan Negara siswa kelas IX - A SMP Negeri 2 Bangkalan, Kabupaten Bangkalan tahun pembelajaran 2013/2014 Semester 1?

\section{Tujuan}

Berdasarkan perumusan masalah diatas, dicapai dalam penelitian ini adalah untuk : 1) Mendiskripsikan dan menganilis mengenai pelaksanaan pourtofolio pada bidang studi Kewarganegaraan dalam pembahasan Hakikat Bangsa dan Negara; 2) Mendiskripsikan dan menganilis prestasi pembelajaran pada bidang studi Kewarganegaraan dalam pembahasan Hakikat Bangsa dan Negara siswa kelas IX - A SMP Negeri 2 Bangkalan, Kabupaten Bangkalan; 3) Mendiskripsikan dan menganilis pengaruh pelaksanaan penilaian portofolio terhadap prestasi belajar pada bidang studi Kewarganegaraan dalam pembahasan Hakikat Bangsa dan Negara siswa kelas IX - A SMP Negeri 2 Bangkalan, Kabupaten Bangkalan.

\section{Manfaat}

Penelitian ini bermanfaat untuk: 1) Menambah pengetahuan guru tentang penilaian portofolio pada bidang studi Kewarganegaraan; 2) Meningkatkan minat belajar siswa dan mendorong siswa untuk berani mengeluarkan pendapat.

\section{E. Tinjauan Pustaka \\ 1. Portofolio}

Portofolio dalam dunia pendidikan mulanya merupakan suatu alternatif penilaian dari suatu proses pembelajaran siswa yang kemudian berkembang sebagai model pembelajaran. Hal ini merupakan kecenderungan baru dalam dunia pendidikan bahwa penilaian dijadikan dasar dalam visi pembelajaran. Pembelajaran portofolio merupakan model pembelajaran yang relatif baru yang merupakan inovasi di dunia pendidikan yang berusaha untuk memotret proses hasil belajar secara holistic, jadi tidak hanya satu ranah kognitif saja. Dalam pembelajaran dan penilaian portofolio telah memiliki konsep yang berbeda dari konsep sebelumnya, ia beranjak dari hanya mengejar kemampuan kognitif menuju kepada "multiple obilities and skills". Untuk selanjutnya kata portofolio dapat dimaknai sebagai penilaian maupun pembelajaran karena dua hal itu tidak dapat saling dipisahkan. Sebenarnya istilah portofolio ini datang dari dunia seni rupa, dimana para seniman memamerkan hasil karya terbaiknya sebagai ungkapan ekspresi diri. Penilaian hasil karya terbaik dalam hal ini adalah menurut dirinya sendiri. Hasil karya yang dimaksud dapat berupa apa saja yang jelas mengandung nilai estetika menurut dirinya, tetapi orang lain pun bisanya juga mengakuinya. Bedanya dengan portofolio dalam pembelajaran kalau portofolio dunia seni yang dipentingkan adalah hasil akhir saja, sedangkan dalam dunia pembelajaran portofolio tidak hanya mementingkan hasil kerja akhir tetapi juga memperhatikan proses dan ini turut dijadikan bahan penilaian.

Pembelajaran dan penilaian poirtofolio ini hanyalah suatu alternatif, tidak ada suatu keharusan dalam pemakaian mengingat kelebihan dan kelemahannya dan disesuaikan kondisi setempat. Berikut ini dikemukakan berbagai pendapat tentang apa yang dimaksud portofolio, guna untuk mendapatkan persmaan dan pemahaman yang sama.

Paulson (1991) mendefinisikan portofolio sebagaikumpulan pekerjaan siswa yang menunjukkan usaha, perkembangan dan kecakapan mereka dalam satu bidang atau lebih. Kumpulan ini harus mencakup partisipasi siswa dalam seleksi criteria penilaian dan bukti refleksi diri. Gronlund (1998) portofolio mencakup berbagai contoh pekerjaan siswa yang tergantung pada keluaran tujuan. Apa yang harus tersurat, tergantung pada subjek dan tujuan penggunaan portofolio. Contoh pekerjaan seperti ini dijadikan dasar bagi pertimbangan kemajuan belajarnya untuk dapat dikomunikasikan kepada siswa, orang serta pihak lain yang berkepentingan. Cathy Grace (1992) definisi portofolio adalah rekaman dari proses pembelajaran siswa apakah siswa itu telah belajar dan bagaimana dia belajar, 
berpikir, bertanya, menganalisis, mensitesis, berkreasi dan bagaimana berinteraksi dengan yang lainnya secara intelektual, emosinal, dan social. Arter, J., Et. Spandel, V. (1991) definisi portofolio adalah kumpulan darihasilkerja siswa dengan tujuan tertentu yang berupa hasil usaha atau pencapaiannya dalam satu bidang atau lebih untuk diperlihatkan kepada siswa itu atau yang lainnya. Todd Bergman, portofolio didefinisikan sebagai kumpulan dari hasil kerja siswa dengan maksud / tujuan tertentu yang menceritakan pencapaian siswa atau perkembangan belajarnya dengan cirri khas isi, visi yang kuat tentang kemampuan dan proses pencapaiannya tersebut selama proses pembelajaran, yang dipilih dengan pamduanpanduan yang telah ditentukan.

Dari berbagai definisi portofolio diatas, secara umum portofolio dapat dimaknai sebagai kumpulan dari semua hasil pekerjaan secara fisik dan catatan mengenai siswa selama proses pencapaian hasil dengan tujuan yang dipilih dengan pamduan-panduan tertentu dan dalam jangka yang didokumentasikan secara baik dan teratur, sehingga dapat dikomunikasikan kepada siswa dan pihak yang berkepentingan yang ingin mengetahui perkembangan belajar siswa itu.

\section{Manfaat Portofolio}

Di era baru ini penilaian hasil belajar dihubungkan dengan monitoring penguasaan siswa pada suatu kurikulum inti, portofolio dapat meningkatkan proses penilaian dengan mengungkap pemahaman dan keterampilan siswa, mendukung tujuan pembelajaran, mencerminkan pertumbuhan dan perubahan setelah jangka waktu tertentu, mendorong siswa dan orang tua untuk dapat merefleksikan diri dan memberikan pendidikan berkesinambungan. Guru dapat menggunakannya untuk berbagai tujuan spesifik, termasuk: a) Mendorong kepada pembelajaran self directed, b) Memperluas cakrawala dari apa yang dipelajari, c) Pengembangan pembelajaran, d) Mendemontrasikan kemajuan kea rah hasilyang jelas, c) Menciptakan suatu titik temu untuk pembelajaran dari penilaian, d) Memberikan kesempatan kepada para siswa untuk menghargai diri mereka sebagai siswa, dan e)
Menawarkan peluang untuk menumbuhkan dukungan dari rekan sebayanya.

\section{Bentuk dan Jenis Portofolio}

a) Portofolio dokumentasi (documentation portofolio):

Portofolio jenis ini merupakan bahan bukti pembelajaran yang dikumpulkan selarasi relevan dan objektif dengan hasil pembelajaran untuk sesuatu tugas tertentu. Proses penyelesaian tugas ditunjukkan dengan jelas dan lengkap (dari bentuk draf hingga hasil akhir). Sebagai tambahan, portofolio bias merupakan suatu rekaman menyangkut aktivitas dari waktu kewaktu dalam pengembangan produk tertulis. Adapun dokumentasi yang dimaksud dapat berupa: a) Bahan bukti pembelajaran (learning evidences) yang relevan dan dihasilkan oleh siswa sendiri seperti esei, laporan, latihan, lembaran kerja, grafik; b) Bukti prestasi siswa seperti kertas ujian, penilaian rekan sebaya; c) Bahan-bahan rujukan, refleksi siswa yang dibuat dari masa ke masa sehubungan aktivitas / pengalaman pembelajaran yang relevan.

b) Portofolio Proses (process portofolio):

Portofolio ini merupakan dokumentasi semua tahap yang menyangkut proses pembelajaran. Hal ini terutama sekali bermanfaat di dalam proses dokumentasi pembelajaran siswa secara keseluruhan yang dapat menunjukkan bagaimana para siswa mengintegrasikan keterampilan atau pengetahuan spesifik dan kemajuan ke arah penguasaan dasar dan lanjut. Portofolio proses menekankan refleksi siswa atas proses belajar, mencakup penggunaan tentang buku catatan harian, catatan pemikiran dan berhubungan dengan bentuk pemrosesan metacognitive.

c) Portofolio hasil terbaik / tampilan (showcase portofolio)

Portofolio hasil terbaik ini digunakan untuk evaluasi sumatif tentang penguasaan siswa terhadap kurikulum intiportofolio ini dipilih dari portofolio adalah suatu proses mengidentifikasi kebutuhan belajar, berdasar pada kebutuhan tersebut, pekerjaan terbaik siswa yang ditentukan guru dan siswa. Pekerjaan yang dimaksud adalah hanyalah hasil kerja yang lengkap. Sebagai tambahan, portofolio jenis ini biasanya dituangkan dalam 
bentuk audio visual, termasuk foto, siaran ulang tv dari video dan arsip rekaman tentang pekerjaan yang diselesaikan siswa. Portofolio jenis ini harus juga meliputi refleksi dan anlisis yang ditulis siswa atas proses pengambilan keputusan yang digunakan untuk menentukan pekerjaan yang dipilihnya.

\section{Pembelajaran Portofolio}

Pembelajaran berbasis portofolio dengan kegiatan merencanakan proses belajar menggunakan sumber daya yang sesuai untuk menemukan kebutuhan dan menunjukkan apa yang sudah dipelajari. Secara sederhana pembelajaran berdasarkan portofolio dapat dipahami sebagai suatu model pembelajaran yang dilakukan dengan mengumpulkan bukti hasil belajar peserta didik dengan upaya mementingkan hasil terbaik dari suatu proses belajar, karena semula pembelajaran ini diilhami dari metode penilaian portofolio. Dasar pengembangan model pembelajaran berbasis portofolio adalah teori belajar konstruktivisme yang pada prinsipnya menggambarkan bahwa siswa membentuk atau membangun pengetahuannya melalui interaksi dengan lingkungannya berdasarkan pengetahuan yang dimiliki sebelumnya.

Sebagai suatu inovasi, model pembelajaran portofolio tidak memposisikan peserta didik sebagai pendengar ceramah guru laksana botol kosong yang diisi dengan ilmu pengetahuan. Melalui model pembelajaran berbasis portofolio peserta didik diberdayakan agar mau dan mampu berbuat untuk memperkaya pengalaman belajarnya (learning to do) dengan meningkatkan interaksi dengan lingkungannya baik lingkungan fisik, social maupun budaya, sehingga mampu membangun pemahaman dan pengetahuannya terhadap dunia disekitarnya (learning to know). Diharapkan hasil interaksi dengan lingkungannya itu dapat membangun pengetahuan dan kepercayaan dirinya (learning to be). Kesempatan berinteraksi dengan berbagai individu atau kelompok yang bervariasi (learning to live together) akan membentuk kepribadiannya untuk memahami kemajemukan dan melahirkan sikap-sikap positif dan toleran terhadap keanekaragaman dan perbedaan hidup.
Dikuatkan oleh pendapat Rutherford dan Ahlgren bahwa murid mempunyai ide sendiri tentang hamper semua persoalan, dimana ada yang benar ada yang salah. Disinilah peran guru dalam pembelajaran dalam mengarahkan murid untuk menuju kepada kebenaran, maka siswa perlu terlibat mulai dari perencanaan hingga penilaiaan proses belajarnya. Isi portofolio dapat ditentukan oleh siswa atau guru atau secara kolaboratif oleh kedua pihak. Hal ini sesuai dengan prinsip yang dianut dalam model pembelajaran berbasis portofolio. Dalam pembelajaran portofolio dokumentasi diperlukan perencanaan, pelaksanaan dan penilaian yang teliti, dimana proses pembelajaran dijalankan secara kolaboratif untuk mencapai pemahaman dan mendokumentasikan pemikiransecara kritis dan kreatif serta pemilihan bahan ajar yang berupa fakta mulai dari yang sederhana (kongkrit) hingga yang komplek (abstrak).

Portofolio sangat bermanfaat dalam memberikan informasi mengenai kemampuan dan pemahaman siswa, memberikan gambaran otentik kepada guru tentang apa yang telah dipelajari siswa, kesulitan dan kendala yang dialami siswa dalam belajar dan jenis bantuan yang diharapkan siswa. Dan juga dapat dijadikan bahan refleksi guru dalam menjalankan tugas pengajarannya. Portofolio juga dapat berguna untuk mendukung kerjasama kelompok dengan menawarkan suatu kesempatan untuk para siswa untuk berbagi dan menafsirkan hasil pekerjaan satu sama lain. Lebih lanjut manfaat pembelajaran portofolio dapan diiventarisasi sebagai berikut: 1) Mengenali dan mendorong pembelajaran secar mandiri; 2) Didasarkan pengalaman nyata sehingga dapat membantu menghubungkan antara teori dan praktik; 3) Dapat menyesuaikan gaya pembelajaran; 4) Mungkinkan penilaian dengan kerangka kriteria yang jelas dengan sasaran hasil pelajaran; 5) Mengakomodasi pembelajaran dari sumber berbeda; dan 6) Menyediakan model untuk pembelajaran seumur hidup.

Filosofi/nilai yang melatarbelakangi penggunaan portofolio menurut Sue Martin (2000): 1) Menggunakan pendekatan konstruktivisme dalam pemahaman 
pembelajaran; 2) Mengakui kecirikhasan dan keanekaragaman pada setiap individu; 3) Penilaian autentik dan menekankan pada proses naturalistic; 4) Menggunakan pendekatan pembelajaran yang ada di tengah lingkungan masyarakat; 5) Penilaiannya berdasarkan perkembangan proses; 6) Penghindaran dalam hal prasangka yang negative terhadap sesuatu; 7) Analisis data/wawancara/penelitian berdasarkan sistem metodologi kualitatif; 8) Konsisten dalam mengintegrasikan keadaan anak-anak dengan kebutuhan khusus; 9) Konsep keandalan/kebenaran dipandang secara individual, tiak secara bersama; 10) Proses penilaian yang mencerminkan refleksi diri/pemikiran kritis; 11) Penekanan pada proses dan juga hasil pembelajaran; 12) Kepekaan kepada kebutuhan belajar secara konstektual dan menghargai sebagai bentuk kebudayaan; 13) Berpusat pada anak dan memberikan sistem penilaian terbuka sesuai kompetensinya masingmasing; dan 14) Mendorong tanggung jawab sekolah untukmenerapkan teknik belajar aktif, menggunakan pendekatan proyek guna mengembangkan kurikulum.

\section{Prisip-prinsip Model Pembelajaran Portofolio}

Proses pembelajaran berbasis portofolio mengacu pada prinsip dasar pembelajaran siswa aktif, kelompok belajar kooperatif dan pembelajaran partisipatorik. Prinsip belajar siswa aktif melalui model pembelajaran ini terlihat hamper diseluruh proses pembelajaran, dari mulai fase perencanaan di kelas, kegiatan lapangan, dan pelaporan. Kelompok belajar kooperatif dikembangkan melalui kerjasama antar siswa dan antar komponen lain di sekolah termasuk kerjasama sekolah dengan orangtua siswa dan lembaga terkait. Kerjasama antar siswa terlihat pada saat proses sudah memilih salah satu masalah untuk bahan kajian bersama. Semua pekerjaan disusun, orang-orangnya ditentukan serta mengerjakan apa, merupakan satu bentuk kerjasama itu. Pembelajaran partisipatorik dikembangkan melalui pelakonan (learning by doing). Salah satu bentuk pelakonan itu adalah siswa belajar hidup berdemokrasi, sebab dalam tiap langkah dalam model ini memiliki makna yang ada hubungannya dengan praktik hidup berdemokrasi.

\section{Pelaksanaan Pembelajaran Portofolio}

Menurut Arnie Pajar (2002) langkahlangkah portofolio sebagai proses belajar mengajar (PBM) dapat dilakukan dengan 6 langkah: 1) Mengidentifikasi masalah yang ada ditengah kehidupan masyarakat. Pada tahap ini terdapat beberapa kegiatan yang dilakukan guru bersama siswa yaitu mendiskusikan tujuan, mencari msalah, serta mengetahui masalah apa saja yang diketahui siswa berkaitan dengan topic yang akan dibahas, serta siswa diberi pekerjaan rumah yang sesuai kemampuan siswa tentang maslah yang ada di tengah lingkungannya. Pekerjaan yang menjadi tugas dirumah tersesbut diharapkan dapat dicari dari berbagai sumber, kemudian dicatat untuk didiskusikan dikelas; 2) Memilih maslah untuk kajian kelas. Sebelum memilih masalah yang akan dipelajari atau di kaji dari daftar masalah yang didapat, hendaknya siswa (kelas) mengkaji terlebih dahulu pengetahuan yang telah mereka miliki mengenai masalah-masalah. Selanjutnya dipilih masalah yang layak secara demokratis dibimbing oleh guru; 3) Mengumpulkan informasi tentang masalah yang akan di kaji oleh kelas. Peran guru pada tahap ini adalah membimbing siswa dalam mendiskusikan sumber-sumber informasi berkenaan dengan masalah yang akan dikaji atau dipelajari, diharapkan dapat mengguanakan sumber informasi yang factual atau nara sumber langsung. Sumber tersebut dapat diperoleh melalui media cetak, atau elektronik (termasuk internet) para pakar, professional, tokoh masyarakat/agama, kantor pemerintah atau swasta atau sumber lainnya. Selanjutnya sumber yang diperoleh dikumpulkan untuk dijadikan portofolio dokumentasi; 4) Membuat portofolio kelas. Pada tahap ini hendaknya siswa telah menyelesaikan telah menyelesaikan penelitian yang memadai untuk memulai membuat portofolio kelas. Alternatif yang mungkin dapat diambi yaitu dengan membentuk empat kelompok dengan tugas masing-masing kelompok; kelompok 1 bertugas menjelaskan masalah yang dikaji, kelompok 2 bertugas menjelaskan berbagai kebijakan alternatif untuk 
mengatasi masalah tersebut, kelompok 3 bertugas mengusulkan kebijakan untuk mengatasi masalah, kelompok 4 bertugas membuat rencana tindakan yang dilakukan untuk pemecahan masalah. Setiap kelompok diharuskan mengartikan hasil pekerjaan apa yang dikumpulkan dari mereka, disini setiap kelompok juga diperbolehkan turut berpartisipasi aktif; 5) Penyajian portofolio (show case portofolio). Penyajian portofolio dilaksanakan setelah kelas menyelesaikan portofolio tampilanmaupun portofolio dokumentasinya. Pelaksanaan dapat dilakukakn pada akhir semsester atau akhir kelas (tergantung situasi dan kondisi sekola). Show case ini ada tiga macam, yaitu dalam kelas, antar kelas, dan antar sekolah. Setiap macam show case diperlukan adanya guru pembimbing dan guru lain sebagai dewan jui atau dapat melibatkan pihak lain yang berkompeten dan berwenang; dan 6) Merefleksi pada pengalaman belajar. Dalam melakukan refleksi pengalaman belajar siswa, guru melakukan upaya evaluasi untuk mengetahui seberapa jauh siswa telah mempelajari berbagai hal yang berkenaan dengan topic yang dipelajari sebagai upaya belajar kelas secara kooperatif. Penyajian portofolio kelas kepada audien yang telah dilakukan, sangat bermanfaat dalam pelaksanaan refleksi ini, sebab pertanyaanpertanyaan dan reaksi-reaksi dari audien memberikan umpan balik yang penting bagi kelas. Langkah tersebut di atas bukanlah harga mati tertentu masih harus disesuaikan dengan topic setiap pembahasan dan mata pelajaran tetapi pokok-pokoknya dapat terwakili seperti langkah di atas.

\section{Penilaian Portofolio}

Perubahan terbaru dalam kebijakan, yang menekankan keterlibatan guru lebih besar di dalam perancangan kurikulum dan menilai para siswa, telah pula meningkatkan suatu daya dorong kepada penggunaan portofolio. Portofolio dihargai sebagai suatu alat penilaian sebab, ketika penyajian prestasi classroombased, mereka dapat secara penuh terintegrasi ke dalam kurikulum. Dan tidak sama dengan test terpisah, portofolio tidak memerlukan banyak waktu karena dapat dilakukan di selssela pelaksanaan pembelajaran portofolio. Lebih dari itu, banyak para guru, pendidik dan peneliti percaya bahwa peneliaian portofolio menjadi lebih efektif disbanding old system untuk mengukur keterampilan akademis, meskipun masih harus di uji keterlaksanaannya. Pelaksanaan portofolio mensyaratkan kejujuran siswa untuk melaporkan hasil belajarnya dan kejujuran dalam menilai kemampuan siswa sesuai dengan criteria yang telah disepakati. Guru harus menunjukkan urgensi laporan yang jujur dari siwa. Adapun bentuk-bentuk penilaian portofolio di antaranya sebagai berikut: 1) Catatan anecdotal, yaitu berupa lembaran khusus yang mencatat segala bentuk kejadian mengenai perilaku siswa, khususnya selama berlangsungnya proses pembelajaran. Lembaran ini memuat identitas yang diambil waktu pengamatan dan lembar rekaman kejadiannya; 2) Ceklist atau daftar cek yaitu daftar yang telah disusun berdasarkan tujuan perkembangan yang harus dicapai siswa; 3) Skala penilaian yang mencatat isyarat kemajuan perkembangan siswa; 4) Respon-p\respon siswa terhadap pertanyaan; dan 5) Tes skrining yang berguna untuk mengidentifikasi keterampilan siswa setelah pengajaran dilakukan, misalnya siswa setelah pengajaran dilakukan, misalnya siswa setealah pengajaran dilakukan, misalnya tes hasil belajar, PR, LKS, Laporan kegiatan lapangan.

Aspek-aspek yang bias di evaluasi menurut Stenmark (1991) sebagai berikut: 1) Pemahaman permasalahan (problem comprehesion); 2) Pendekatan dan strategi (approaches and strategies); 3) Hubungan (relationship); 4) Fleksibilitas (flexibility); 5) Komunikasi (communication); 6) Dugaan dan hipotesis (curiosty and hypotheses); 7) Persamaan dan keadilan (equality and equity); 8) Penyelesaian (solutions); 9) Hasil pengujian (examining result); dan 10) Penilaian mandiri (self assessment)

Salah satu bagian penting dari penilaian portofolio adalah mengajukan pertanyaan. Mengajukan pertanyaan yang benar merupakan suatu seni sehingga guru berlatih dalam hal ini. Contoh pertanyaan yang bisa diajukan untuk 
mengevaluasi aspek fleksibilitas dengan tujuan untuk mengambil atau mengetahui apakah siswa bisa menggunakan/menggantikan dengan cara lainnya bila sesuatu tidak dikerjakan dengan cara yang telah diberikan, apakah mereka teguh dalam usahanya, dan apakah mereka mencoba yang lain. Untuk tujuan tersebut bisa diajukan pertanyaan sebagai berikut: 1) Apakah kamu telah mencoba atau hanya menebak? 2) Apakah kamu bisa menyelesaikan dengan menggunakan cara lain? 3) Apa lagi yang telah kamu coba? dan 4) Coba tunjukkan masalah sejenis,apakah ini masalah yang lebih mudah?

Sedangkan dalam aspek hubungan yang tujuannya adalah untuk mengungkap apakah siswa melihat hubungan ide utamanya, apakah mereka mengaitkan masalah dengan masalah serupa yang telah dipelajari terdahulu. Pertanyaan-pertanyaan, yaitu sebagai berikut: 1) Apakah hubungan yang ini dengan yang itu? 2) Apa kesamannya? Apa perbedaannya? 3) Apakah ada polanya? 4) Misalnya kita mengambil bagian ini, akan jadi apakah sisanya? 5) Bagaimana jika kamu memindahkan bagian ini? dan 6) Dapatkah kamu menulis masalaha lain yang berkaitan dengan masalah ini?

Mengevaluasi portofolio bukanlah suatu tugas yang mudah sebab tidak pernah ada dua portofolio yang tepat sama, hal ini disebabkan individu yang menyiapkan portofolio akan mengikutsertakan item-item yang berbeda tersebut dengan kelebihan yang dimilikinya. Salah satu cara untuk mengevaluasi portofolio adalah dengan penggunaan statistic. Cara ini menggunakan skala nilai untuk member skor pada item yang mengharuskan murid menjawabnya dalam bentuk tulisan dengan jawaban yang banyak (open-open item) pada soal yang diberikan. Murid bebas menjawab (free response question) atau terdapat berbagai cara untuk memperoleh jawaban.

\section{Mata Pelajaran Kewarganegaraan \\ a. Pengertian Kewarnegaraan}

Pendidikan Pancasila

dan

Kewarganegaraan adalah bahan pembelajaran yang digunakan sebagai wahana untuk mengembangkan dan melestarikan nilai luhurdan moral yang berakar pada budaya bangsa Indonesia yang diharapkan dapat diwujudkan dalam bentuk perilaku daalam kehidupan sehari-hari peserta didik, baik sebagai individu maupun sebagai anggota masyarakat dan makhluk ciptaan Tuhan Yang Maha Esa. Salah satu fungsi pendidikan Kewarganegaraan yaitu mengembangkan dan melestarikan nilai dan moral Pancasila secara dinamis dan terbuka. Dinamis yang terbuka dalam arti bahwa nilai yang dikembangkan mampu menjawab tantangan perkembangan yang terjadi dalam masyarakat tanpa kehilangan jati diri sebagai bangsa Indonesia yang merdeka, bersatu dan berdaulat.

\section{b. Pembahasan Hakikat Bangsa Dan Negara Tujuan Negara.}

Tujuan Negara diperlukan oleh setiap bangsa karena dapat dijadikan arah kegiatan dan pedoman penyusun alat perlengkapan Negara dan badan pemerintah. Tujuan Negara juga menunjukkan apa yang secara idiil hendak dicapai oleh Negara itu. Namun demikian, rumusan tujuan Negara tentu berbeda-beda. Hal ini tergantung pada tempat, keadaan, waktu serta sifat dari kekuasaan penguasa. Beberapa tujuan Negara menurut para ahli antara lain: Roger H. Soltau, mengatakan bahwa tujuan Negara adalah memungkinkan rakyatnya berkembang serta menyelenggarakan daya ciptanya sebebas mungkin, Harold J. Laski, mengemukakan bahwa tujuan Negara adalah menciptakan keadaan dimana rakyatnya dapat mencapai keinginan-keinginannya secara maksimal, dan John Locke, menganggap bahwa tujuan Negara adalah kebaikan umat manusia.

\section{c. Pengaruh Antara Penilaian Portofolio dengan Prestasi Mata Pelajaran Kewarganegaraan}

Di atas telah disebutkan bahwa penilaian portofolio dimaksudkan untuk memantau kemajuan belajar peserta didik selama pelaksanaan mengikuyi kegiatan belajar mengajar, dan untuk memberikan balikan bagi penyempurnaan program belajar, serta untuk mengetahui kelemahan-kelemahan yang memerlukan perbaikan, sehingga hasil prestasi belajar siswa menjadi lebih baik. Demikian pula 
bila penilaian portofolio tersebut dilakukan kepada siswa, maka akan menimbulkan motivasi dalam diri siswa, sehingga hasil prestasi belajarnya akan meningkat. Hal ini sesuai dengan pendapat Eddy Soewardi Karta Wijaya (1998:30) yang mengatakan bahwa untuk mendapatkan hasil evaluasi belajar yang lebih mantap, maka evaluasi dalam wujud penilaian portofoliodapat dilaksanakan beberapa kali sebelum tiba masanya untuk melakukan evaluasi pada akhir semester. Demikian pula halnya dalam bidang studi Kewarganegaraan, semakin seringnya pelatihan soal-soal diberikan dan penilaian portofolio dilakukan, maka siswa memiliki pengetahuan dan keterampilan dalam menyelesaikan soal-soal Kewarganegaraan tersebut, serta lebih menguasai dan mendalami materi Kewarganegaraan. Pernyataan tersebut sesuai dengan pendapat Herman Hudoya (1995:15) menyatakan bahwa makin sering suatu konsep pelajaran itu diulangi dan dinilai, maka makin dikuasailah konsep pelajaran itu, dan dengan demikian dapat memberikan motivasi belajar pada diri siswa, sehingga dapat meningkatkan prestasi belajarnya.

\section{F. Metodologi Penelitian}

Berdasarkan tujuan yang telah ditetapkan, yaitu untuk memperoleh gambaran tentang pengaruh pelaksanaan penilaian portofolio terhadap prestasi belajar pada bidang studi Kewarganegaraan dalam pembahasan Hakikat Bangsa Dan Negara, maka metode penelitian yang sesuai dengan penelitian ini adalah metode statistic korelasional. Pemakaian metode ini didasarkan pada teori Sumadi Suryabrata yang berbunyi: "Tujuan penelitian korelasional adalah untuk mendeteksi sejauh mana variasivariasi pada satu atau lebih factor lain berdasarkan koefisien korelasi”. (Sumadi Suryabrata (1993:26). Penggunaan metode dalam setiap penelitian, memang mempunyai peranan yang sangat penting, dimana metode penelitian ini membicarakan tata kerja dan caracara pemecahannya secara sistematis yang ditempuh seorang peneliti dengan sebaikbaiknya, sehingga hasilnya dapat dipertanggungjawabkan secara ilmiah. Hal ini sesuai dengan pendapat Sutrisno Hadi: "Metodologi research sebagaimana yang kita kenal sekarang membicarakan garis-garis yang sangat cermat dan mengajukan saran-saran yang sangat kerap, maksudnya adalah untuk menjaga agar pendapat mempunyai harga ilmiah yang setinggi-tingginya". (Sutrisno Hadi, (1993:4).

\section{Rancangan Penelitian}

a. Kegiatan Awal. Sebelum penyusunan rancangan terlebih dahulu ditentukan tema atau judul penelitian.

b. Survey Penelitian. Sebelum penelitian dilaksanakan terlebih dahulu diadakan observasi lapangan, dengan tujuan untuk meyakinkan bahwa penelitian bisa dilakukan dan dapat berjalan lancer serta tidak akan menemui hambatan yang berarti.

c. Penyusunan Instrumen Penelitian. Setelah melakukan survey penelitian, maka langkah selanjutnya adalah menyusun instrument penelitian. Penyusunan instrument ini dalam rangka pengumpulan data, sehingga cara kerja akan lebih baik dan terarah serta dapat dipertanggungjawabkan.

d. Pelaksanaan Penelitian. Setelah semua persiapan penelitian selesai, maka langkah selanjutnya adalah melaksanakan penelitian. Adapun pelaksanaan penelitian ini dalam upaya mencari, menentukan, mengolah dan menganalisis data dalammembuktikan pernyataan hipotesis yang telah ditentukan. Adapun kegiatannya adalah sebagai berikut; 1) Mengadakan orientasi lapangan; 2) Mengadakan kunjungan kelas yang akan dijadikan obyek penelitian; 3) Memberikan penyuluhan tentang pentingnya penilaian portofolio terhadap prestasi belajar pada bidang studi Kewarganegaraan; 4) Memberi tugas pembuatan kliping tentang Perkembangan dan Pelaksanaan Ketatanegaraan Indonesia dari berbagai sumber kepada siswa yang dijadikan subyek penelitian, dan dikumpulkan kembali kemudian dilakukan penilaian secara portofolio dengan menggunakan Skala Linkter; 5) Diadakan wawancara dengan rekan guru dan dengan siswa; 6) Mencari data dari leger atau rapor untuk bidang studi Kewarganegaraan; dan 7) Menganalisis dan membuat laporan hasil penelitian. 


\section{Populasi Dan Sampel}

Dalam penelitian ini yang bertindak sebagai populasi adalah semua siswa Kelas IXA SMP Negeri 2 Bangkalan, Kabupaten Bangkalan tahun pembelajaran 2013/2014. Sampel adalah "...sebagian dari populasi terjangkau yang memiliki sifat sama dengan populasi” (Nana Sudjana, 1989:85). Sedang menurut Suharsimi, sampel adalah "sebagian atau wakil populasi yang akan diteliti" (Suharsimi Arikunto, 1987:1).

\section{Variabel Penelitian}

a. Variabel Bebas (independent). Variabel bebas (independent) atau variabel $\mathrm{X}$ adalah variabel yang tidak terpengaruh karena perubahan keadaan variabel lain. Dalam penelitian ini yang menjadi variabel bebas (independent) adalah pelaksanaan penilaian portofolio.

b. Variabel Terikat (dependent). Sebagai Variabel terikat (dependent) atau variabel Y adalah variabel yang tergantung pada variabel lain. Dalam penelitian ini yang menjadi variabel terikat (dependent) adalh prestasi belajar siswa pada bidang studi kewarganegaraan, khususnya pada materi Hakikat Bangsa dan Negara.

\section{Instrument Penelitian}

Instrument yang digunakan dalam penelitian ini adalah: a) Pedoman pertanyaan wawancara sebagai pelengkap atau penunjang untuk mendapatkan data mengenai pelaksanaan penilaian portofolio pada bidang studi Kewarganegaraan dalam pembahasan Hakikat Bangsa dan Negara, 2) Dokumentasi hasil tes berupa tugas kliping pada bidang studi Kewarganegaraan dalam pembahasan Hakikat Bangsa dan Negara.

\section{Teknik Pengumpulan Data}

Adapun teknik yang digunakan dalam pengumpulan data dalam penelitian ini adalah sebagai berikut: a) Studi Kepustakaan (Library Reseacrh), yaitu pengambilan data dengan mempelajari buku, majalah, literature dan sebagainya yang erat hubungan dengan penelitian; b) Studi Lapangan (Field Research), yaitu untuk memperoleh data-data secara langsung dari sekolah yang bersangkutan dengan permasalhan yang akan dibahas dan data tersebut dikumpulkan dengan jalan : studi pendahuluan, studi pelaksanaan lapangan.

Adapun metode yang digunakan dalam pengumpulan data adalah metode angket, metode dokumentasi, metode wawancara, dan metode observasi.

\section{Teknik Analisis Data}

Analisis data merupakan tahap akhir dari suatu penelitian, yaitu mengolah data yang dikumpulkan kemudian mengambil kesimpulan apakah hipotesis yang dirumuskan diterima atau ditolaknya. Pengujian hipotesis yang peneliti gunakan adalah teknik korelasi produck moment dari pendapat Suharsimi Arikunto, dengan rumus sebagai berikut:

$$
\mathrm{r}_{\mathrm{xy}}=\frac{\Sigma \mathrm{xy}}{\sqrt{\left(\Sigma \mathrm{x}^{2}\right)\left(\Sigma \mathrm{x}^{2}\right)}}
$$

\section{Penyajian Data}

Pada bagian ini disajikan data hasil penelitian. Ada 2 (dua) bagian antara lain : a) Daftar nilaipengumpulan data, yang diambil melalui menyebarkan angket kepada siswa responden Kelas IX-A SMP Negeri 2 Bangkalan tahun pembelajaran 2013/2014 Semester 1, b) Dokumentasi data hasil tes berupa tugas kliping pada bidang studi kewarganegaraan dalam pembahasan Hakikat Bangsa dan Negara siswa responden Kelas IX-A SMP Negeri 2 Bangkalan tahun pembelajaran 2013/2014.

\section{G. Hasil Analisis Data}

Berbagai usaha yang dilakukan oleh manusia, baik perorangan maupun secara tim pasti memiliki tujuan tertentu. Tujuan ini ditetapkan berdasarkan pengalaman yang pernah diperoleh. Berdasarkan dari hasil penguji hipotesis diatas $r=0.673$. Dengan demikian hipotesis berbunyi : ada hubungan positif yang signifikan, antara nilai hasil pengumpulan data yang diambil melalui penyebaran angket tentang pelaksanaan penilaian portofolio dan prestasi pembelajaran berupa nilai hasil tes tugas kliping bidang studi kewarganegaraan dalam pembahasan Hakikat Bangsa dan Negara siswa responden kelas IX-A SMP Negeri 2 Bangkalan tahun pembelajaran 2013/2014 semester 1 dapat diterima 


\section{H. Simpulan dan Saran \\ 1. Simpulan}

Berdasarkan analisis data yang dilakukan dengan menggunakan data statistic korelasi produck menurut $\left(\mathrm{r}_{\mathrm{xy}}\right)$ tentang, pelaksanaan penilaian portofolio dengan peningkatan prestasi pembelajaran pada bidang studi kewarganegaraan menghasilkan $r_{x y}=0.673$ dari sampel yang diambil sejumlah 38 responden. a) Hipotesis alternative atau hipotesis kerja diterima artinya ada hubungan atau korelasi yang positif antara pelaksanaan penilaian portofolio dengan prestasi pembelajaran pada bidang studi kewarga negaraan dalam pembahasan Hakikat Bangsa dan Negara siswa kelas IX-A SMP Negeri 2 Bangkalan tahun pembelajaran 2013/2014 hal ini berarti bahwa jika pelksanaan penilaian portofolio biasa berlangsung secara baik, maka prestasi pembelajaran siswa pada b idang studi kewarganegeraan akan baik pula; b) Pelaksanaan-pelaksanaan penilaian portofolio yang skor rata-ratanya $252: 38=6.63$ adalah tergolong cukup baik; dan c) Prestasi pembelajaran siswa pada bidang studi kewarganegaraan yang skor rata-ratanya 268 : $38=7.05$ adalah tergolong cukup baik.

\section{Saran}

Sebagai akhir dari kegiatan penelitian ini, maka saran-saran yang dapat dikemukakan sebagai berikut : a) Bagi kepala sekolah. Karena pelaksanaan penilaian portofolio merupakan salah satu masukan untuk meningkatkan kualitas keberhasilan siswa dalam pembelajaran, tentunya harus disediakan suatu fasilitas yang cukup memadai agar para guru dan siswa dapat melakukan aktifitas pembelajaran secara efisien dan efektif; b) Bagi guru. Dari hasil penelitian Nampak sekali bahwa pelaksanaan penilaian portofolio berpengaruh baik pada prestasi siswa, utamanya pada bidang studi kewarganegaraan. Untuk itu, hendaknya para guru mampu melaksanakan dan menerapkan penilaian portofolio secara wfwktif dan efisie. Keberhasilan yang dicapai siswa hendaknya lebih bisa ditingkatkan dan selalu dibina agar tidak salah arah. Hal itu bisa dilakukan dengan cara memberikan kesempatan dan fasilitas yang cukup pada meraka agar lebih bisa mengikuti pelaksanaan penilaiaan portofolio yang sesuai dengan perkembangan pribadi mereka; c) Bagi Pembaca. Hasil penelitian ini hendaknya dapat dijadikan sebagai bahan pertimbangan bila berkehendak untuk melakukan hal-hal yang berkaitan dengan pelaksanaan penilaian portofolio dan peningkatan orestasi pembelajaran siswa pada bidang studi kewarganegaraan.

\section{DAFTAR PUSTAKA}

Arnie Fajar, 2022. Portofolio dalam pelajaran IPS. Bandung: Remaja Rosdakarya. .........portofolio Based Learning. WWW.Primarycare-uwcm.ac.ak. Diakses 10 Oktober 2003

Boediono, dkk.2001. Kurikulum Berbasis KomQetensi. Jakarta: Balitbang Depdiknas.

Budimansyah, Dasim, dkk. 2001. Apa dan Mengapa Model Pembelajaran

Berbasis Portofolio? Makalah disampaikan Pada Diklat Guru SLTP Jawa Barat di Lembang 2002. Mengenal Model Pembelajaran dan Penilaian Berbasis Portofolio. Makalah disampaikan Pada Diklat Guru SLTP Kabupaten Sumedang di Sumedang.

Imron, All. 1996. Belajar dan Pembelajaran. Jakarta: Pustaka Jaya.

Kartini, Kartono, 1980. Metodologi Research. Bandung : Alumni.

Mattew Kaplan, The Teaching Portofolio. www.clrt.umich.edu/publinks/CLRT noll.pdf. Diakses 20 September 2003

Patton, Michael Quin. 1986. Qualitative Evaluation Methods. Beverly Hill London: Sage Publication Inc

Poewardarminto, W.J.S. 2002. Kamus Umum Bahsa Indonesia. Jakarta: Balai Pustaka

Purwanto, Ngaliman M.P. 1990. Psikologi Pendidikan. Bandung: PT. Remaja Ros Pakarya.

Suharsimi, Arikunto. 1999. Dasar-dasar Evaluasi Pendidikan. Jakarta: Bumi Aksara. 
Sujana, 1996. Metode Statistika. Bandung: Transito

Sujanto, Agus. 1979. Psikologi Umum Jakarta: Bumi Aksara

Sutrisno, Hadi. 1999. Statistika 11 Yogyakarta: Yayasan Fakultas Psikologi Universitas Gajah Mada.

Tabrani, Rusyan, A. 1999. Penuntun Belajar Yang Sukses. Jakarta: Nine Karya Jaya.

Tim MKDK. 1996. Metode Statistika. Surabaya: University Press IKIP Surabaya.

Wahyuti, Maryono. 2002, Kurikulum Berbasis Kompetensi. Bandung: Balai Pendidikan Guru.

Walgito, Bimo. 2000. Bimbingan dan Penyuluhan di Sekolah edisi_ IV. Yogyakarta: Yayasan Penerbitan Fakultas Psikologi Universitas Gajah Mada. 